\title{
KEBERADAAN MASYARAKAT PENDATANG DI DESA SUKAKERTA (PERUBAHAN SOSIAL BUDAYA MASYARAKAT TERKAIT PEMBANGUNAN BANDARA INTERNASIONAL JAWA BARAT DI KECAMATAN KERTAJATI, KABUPATEN MAJALENGKA)
}

\author{
Oleh: \\ Yosi Damayanti, Hetty Krisnani, Meilanny Budiarti S. \\ E-mail : \\ ysdmynt@gmail.com
}

\begin{abstract}
ABSTRAK
Pemerintah Provinsi Jawa Barat memiliki keinginan untuk memiliki bandara bertaraf internasional. Studi kelayakan telah dilakukan terhadap beberapa wilayah di Provinsi Jawa Barat. Hasil uji kelayakan wilayah menetapkan Kecamatan Kertajati, Kabupaten Majalengka sebagai tempat pembangunan bandar udara bertaraf internasional yang kemudian diberi nama Bandar Udara Internasional Jawa Barat (BIJB) atau Bandar Udara Kertajati. Pembangunan Bandar Udara Internasional Jawa Barat (BIJB). Pembangunan Bandar Udara Internasional Jawa Barat (BIJB) memerlukan wilayah yang cukup luas dan mencakup lahan yang sekarang menjadi tempat pemukiman dan pertanian sehingga diperlukan relokasi pemukiman warga. Relokasi dilakukan secara bertahap dan masih secara swadaya. Desa Sukakerta merupakan wilayah dengan jumlah migrasi masuk yang cukup banyak sehingga mengindikasikan telah membuat terjadinya perubahan sosial budaya masyarakat pendatang di Desa Sukakerta. Masyarakat pendatang secara otomatis melakukan adaptasi sehingga turut mempengaruhi kehidupan sosial budaya di daerah tempat tinggal barunya yaitu Desa Sukakerta. Penelitian ini bertujuan untuk mengidentifikasi aspek-aspek dari perubahan sosial budaya masyarakat yang mempengaruhi kehidupan masyarakat pendatang sebagai akibat dari relokasi terhadap pembangunan Bandar Udara Internasional Jawa Barat (BIJB). Metode penelitian yang dilakukan yaitu penelitian deskriptif dengan metode kualitatif. Metode kualitatif dilakukan dengan mewawancarai berbagai stakeholder yang terkait, masyarakat pendatang, dan masyarakat asli Desa Sukakerta. Aspek-aspek sosial budaya yang diteliti meliputi nilai dan norma sosial, pola perilaku, dan interaksi sosial (aspek sosial) serta sistem peralatan hidup dan teknologi, sistem ekonomi dan mata pencaharian (aspek budaya).
\end{abstract}

Kata kunci : BIJB, relokasi, masyarakat, perubahan sosial budaya

\section{ABSTRACT}

The goverment of West Java Province have a desire to have an international airport. A feasibility study has been done on several areas in west java province. The results of the test the feasibility of setting district Kertajati, Majalengka development as a destination airport international and then given the name of the international airport west java (BIJB) or airport Kertajati. The development of the international airport west java (BIJB). The development of the international airport west java (BIJB) requires considerable territory broad and covers land now become a residential and 
agricultural relocation that required residential areas .Relocation was conducted gradually and still independently. Sukakerta village was the area with the number of migration in enough so that indicates has made the occurrence of social change the culture of the newcomers in the village sukakerta. The newcomers automatically do adaptation So that also influence social and cultural life in the village is Sukakerta his new place of residence. This research aims to identify the aspects of community social and cultural changes that affect the life of the newcomers as a result of relocation to the development of international airport west java (BIJB). A method of research conducted with a method of qualitative research is descriptive. The qualitative method conducted by interviewing related various stakeholders, the newcomers, and the native village Sukakerta. Social and cultural aspects and the treatment includes the value of social norm, pattern of behavior, social interaction (social aspects) and of life as well as equipment and technology system, the economic system and livelihoods (cultural aspects).

Keyword : BIJB, relocation, community, social and cultural change

\section{PENDAHULUAN}

Pembangunan Bandar Udara Internasional Jawa Barat (BIJB)

Selama ini bandar udara Husein Sastranegara yang terletak di Bandung telah menjadi bandar udara dengan aktivitas penerbangan yang sangat ramai. Masyarakat dapat dikatakan hidup secara dinamis dan berkembang mengikuti jaman. Begitu pula masyarakat di Provinsi Jawa Barat yang memiliki aktivitas yang melampaui batasan wilayah. Tentunya harus didukung dengan penambahan atau peningkatan fasilitas transportasi. Transportasi udara merupakan sarana transportasi yang banyak dinikmati masyarakat, dikarenakan waktu tempuh perjalanan menjadi lebih cepat dan efektif. Oleh karena itu sejak tahun 2002 pemerintah Provinsi Jawa Barat memiliki keinginan untuk menambah bandar udara di wilayahnya. Studi kelayakan wilayah dilakukan di beberapa wilayah Provinsi Jawa Barat. Menurut Keputusan Menteri Perhubungan No: KM 34 tahun 2005 sesuai dengan hasil uji kelayakan wilayah menetapkan Kecamatan Kertajati, Kabupaten Majalengka sebagai tempat pembangunan bandar udara bertaraf internasional. Pembangunan bandar udara di Kecamatan Kertajati, Kabupaten Majalengka selain merespon kebutuhan masyarakat, juga merupakan upaya pengembangan daerah Provinsi Jawa Barat khusunya wilayah
"CIAYUMAJAKUNING" yaitu Cirebon, Indramayu, Majalengka dan Kuningan sesuai dengan Peraturan Daerah Provinsi Jawa Barat No.13 Tahun 2010. Pembangunan bandar udara tersebut kini telah berlangsung dan terbilang strategis karena disertai dengan pembangunan fisik infrastruktur pendukung yaitu jalan tol Cikampek-Palimanan (Cikapali) dan jalan tol Cileunyi-Sumedang-Dawuan (Cisumdawu). Pembangunan fisik infrastruktur penunjang tersebut diharapkan dapat memperpendek waktu tempuh antar wilayah sehingga dapat meningkatkan pertumbuhan investasi dan sektor pariwisata sehingga dapat meningkatkan Indeks Pembangunan Manusia (IPM) di wilayah Kabupaten Majalengka. UNDP (United Nation Development Programme) mendefinisikan pembangunan manusia sebagai suatu proses untuk memperluas pilihan-pilihhan bagi penduduk. Dalam konsep tersebut penduduk ditempatkan sebagai tujuan akhir (the ultimated end) sedangkan upaya pembangunan dipandang sebagai sarana (principal means) untuk mencapai tujuan itu. Masyarakat Kabupaten Majalengka khususnya Kecamatan Kertajati menyambut pembangunan bandar udara tersebut dengan persepsi yang positif. Pemerintah terkait telah berhasil mensosialisasikan pembangunan bandar udara dengan baik. Dengan pembangunan bandar udara di wilayahnya masyarakat Kecamatan 
Kertajati percaya akan meningkatkan kesejahteraan dan mendatangkan keuntungan. Meskipun tidak selamanya pembangunan akan membawa dampak positif, tentunya akan ada dampak negatif menyertainya. Masyarakat perlu dipersiapkan untuk menghadapi perubahan-perubahan yang mendasar dalam kehidupannya. Perubahan memerlukan proses penyesuaian terhadap kehidupan baru. Ketika pembangunan bandar udara telah selesai akan membuka lapangan pekerjaan yang baru, baik di bidang industri, jasa, perdagangan maupun bidang lainnya. Penting untuk melibatkan pasrtisipasi masyarakat setempat, agar mereka nantinya tidak hanya menjadi "penonton" dari kemajuan daerahnya.

Bandara Internasional Jawa Barat (BIJB) dibangun sesuai dengan Peraturan Menteri Perhubungan Nomor: KM 34 Tahun 2005 tentang Penetapan Lokasi Bandar Udara di Kecamatan Kertajati, Kabupaten Majalengka, Provinsi Jawa Barat:

1. Pasal 1, Ayat (1): Lokasi bandar udara di Kecamatan Kertajati, Kabupaten Majalengka, Propinsi Jawa Barat berada di Kecamatan Kertajati, Kabupaten Majalengka, dengan Koordinat Geografis $06^{\circ} 39^{\prime} 27,89^{\prime}$ 'Lintang Selatan dan $108^{\circ}$ 10' $27^{\prime}, 44^{\prime \prime}$.

2. Pasal 2, Ayat (1): Luas rencana kebutuhan lahan untuk pembangunan bandar udara di Kecamatan Kertajati, Kabupaten Majalengka, sebagaimana dimaksud dalam Pasal 1 seluas $\pm 1800 \mathrm{Ha}$, yang selanjutnya akan ditentukan lebih rinci berdasarkan rencana induk bandar udara di Kabupaten Majalengka.

Bandar udara bertaraf internasional yang kemudian diberi nama Bandar Udara Internasional Jawa Barat (BIJB) atau Bandar Udara Kertajati memerlukan lahan untuk kawasan inti sekitar 1800 hektare sesuai dengan yang tertera dalam Rencana Tata Ruang dan Wilayah (RTRW) Kabupaten Majalengka tahun 2011-2031. Lahan yang digunakan dalam pembangunan bandar udara tersebut sebagian besar merupakan lahan pemukiman dan lahan pertanian masyarakat di beberapa wilayah desa. Terdapat 5 (lima) desa di Kecamatan Kertajati yaitu Desa Kertajati, Desa Kertasari, Desa Bantarjati, Desa Sukamulya, dan Desa Sukakerta yang wilayahnya dipergunakan dalam pembangunan Bandar Udara Internasional Jawa Barat (BIJB) dan harus dibebaskan kepemilikan tanahnya. Diperkuat oleh data yang termuat dalam publikasi Badan Pusat Statistik Kabupaten Majalengka (2014: 7), tahun 2013 ada perubahan jumlah pemerintahan berdasarkan satuan dusun, RW dan RT. Ada beberapa dusun yang hilang dari beberapa desa, diantaranya Dusun Cintakarya di Desa Kertajati, Dusun Sukasari di Desa Kertasari dan Dusun Sukahayu di Desa Babakan.

Tabel 1 Jumlah Dusun, RW dan RT Per Desa Tahun 2013

\begin{tabular}{|c|c|c|c|}
\hline Desa & $\begin{array}{c}\text { Jumlah } \\
\text { Dusun }\end{array}$ & $\begin{array}{c}\text { Jumlah } \\
\text { RW }\end{array}$ & $\begin{array}{c}\text { Jumlah } \\
\text { RT }\end{array}$ \\
\hline Kertajati & 5 & 5 & 8 \\
\hline Kertasari & 3 & 3 & 5 \\
\hline Bantarjati & 2 & 4 & 7 \\
\hline Sukamulya & 3 & 7 & 17 \\
\hline Sukakerta & 3 & 4 & 8 \\
\hline
\end{tabular}

Sumber: Kecamatan Kertajati Dalam Angka Tahun 2014, BPS Kab. Majalengka

Pembebasan lahan dilakukan untuk memperlancar pembangunan bandar udara tersebut. Pemerintah dan pihak terkait melakukan pembebasan lahan dengan membayarkan sejumlah uang ganti rugi kepada masyarakat. Masyarakat yang telah menerima uang ganti rugi secara otomatis harus meninggalkan tempat pemukiman sebelumnya. Masyarakat melakukan perpindahan tempat pemukiman secara swadaya dan menyebar ke beberapa tempat. Belum ada upaya dari pemerintah untuk 
merencanakan pola perpindahan tempat pemukiman penduduk yang terorganisir. Perpindahan penduduk yang datang maupun pergi dari kelima desa tersebut terlihat signifikan. Menurut sumber BPS Kabupaten Majalengka yang telah diterbitkan kedalam laporan Kecamatan Kertajati Dalam Angka Tahun 2014, dapat dilihat jumlah perpindahan penduduk datang dan pergi. Berdasarkan tabel terlihat mobilitas penduduk pindah terbanyak di dua desa yaitu Desa Kertajati dan Kertasari, sedangkan mobilitas penduduk datang terbanyak di dua desa yaitu Desa Sukamulya dan Desa Sukakerta.

Menarik untuk menelusuri masyarakat pendatang ke Desa Sukakerta. Masyarakat yang melakukan perpindahan tempat pemukiman dengan datang ke wilayah baru tentu akan mengalami proses adaptasi sebagai bentuk penyesuaian terhadap perubahan kondisi sosial dan budaya. Mereka akan mengalami perbedaan pola hidup, kebiasaan dan perilaku di tempat barunya. Adaptasi sebagai hal alamiah yang dilakukan setiap individu dalam masyarakat untuk merespon perubahan-perubahan yang terjadi di sekitarnya. Fleksibilitas ditunjukan masyarakat mengubah dirinya sesuai dengan kondisi yang diinginkannya melalui usahausaha atau perilaku untuk menghadapi hambatan atau hal baru yang terjadi. Selain itu terbentuk pola kehidupan baru antara masyarakat pendatang dan masyarakat asli Desa Sukakerta. Dinamika kelompok tentunya akan muncul dalam kehidupan bermasyarakat. Masyarakat pendatang dan masyarakat asli Desa Sukakerta keduanya bersiap dan sedang merasakan secara langsung dampak sosial dari pembangunan Bandar Udara Internasional Jawa Barat (BIJB). Uang ganti rugi sebagai pengganti kepemilikan lahan mereka Derta merta akan merubah kehidupan mereka. Berdasarkan fenomena yang telah diuraikan diatas penelitian ditujukan Kentadri mendeskripsikan keberadaan massarakatat pendatang di Desa Sukakerta beserta dinamika kehidupannya ketika pembangunan Spałkalya udar Internasional Jawa Barat S(ARhkBita berlangsung. Penelitian dilakukan dengan mengedepankan aspek-aspek perubahan sosial budaya yang meliputi nilai dan norma sosial, pola perilaku, dan interaksi sosial (aspek sosial) serta sistem peralatan hidup dan teknologi, sistem ekonomi dan mata pencaharian (aspek budaya).

\section{KAJIAN PUSTAKA}

Migrasi Penduduk

Migrasi diartikan sebagai perpindahan penduduk dengan tujuan untuk menetap dari suatu tempat ke tempat lain melalui batas politik atau negara atau batas administrasi atau batas bagian dari suatu negara.

Perserikatan Bangsa-Bangsa (PBB) merumuskan migrasi penduduk sebagai suatu perpindahan tempat tinggal dari suatu unit administrasi ke unit administrasi yang lain (United Nations 1970:1). Sedangkan Gould dan Prothero (1975:41) menekankan unsur perpindahan tempat tinggal, namun menurut mereka, walaupun seseorang telah secara resmi pindah tempat, tetapi apabila ada niat sebelumnya untuk kembali ke tempat semula, maka harus dianggap sebagai mobilitas sirkuler, bukan sebagai migrasi. Migrasi merupakan perpindahan penduduk dari suatu wilayah lain dengan maksud untuk menetap di daerah tujuan. Konsep migrasi berkaitan dengan ruang dan waktu.

Tabel 2

Jumlah Penduduk Datang dan Pindah Menurut Jenis Kelamin Per Desa Tahun 2013 
Sumber : Kecamatan Kertajati Dalam Angka Tahun 2014, BPS Kab. Majalengka

Jenis-jenis migrasi

Perpindahan penduduk akan terkait dengan tempat atau wilayah, waktu atau penduduk yang datang dan penduduk yang pergi. Ruang lingkup migrasi mencakup wilayah administrasi dari yang tersempit yaitu RT atau $\mathrm{RW}$, desa hingga ruang lingkup yang luas yaitu perpindahan antar negara. Dari segi waktu migrasi dapat dibedakan pula mulai dari satu hari hingga waktu yang cukup lama. Maka migrasi dapat dibedakan menjadi beberapa jenis, yaitu:

1. Migrasi masuk (in migration), masuknya penduduk ke suatu daerah tujuan.

2. Migrasi keluar (out migration), perpindahan penduduk keluar dari suatu daerah asal.

3. Migrasi netto (net migration), selisih antara jumlah migrasi masuk dan migrasi keluar.

4. Migrasi bruto (gross migration), jumlah migrasi masuk dan migrasi keluar.

5. Migrasi total (total migration), seluruh kejadian migrasi, mencakup migrasi semasa hidup dan migrasi pulang.

6. Migrasi semasa hidup (life time migration), migrasi berdasarkan tempat kelahiran, mereka yang pada waktu pencacahan sensus bertempat tinggal di daerah yang berbeda dengan daerah tempat lahirnya.

7. Migrasi parsial (partial migration), jumlah migran ke suatu daerah tujuan dari daerah asal atau dari daerah asal ke suatu daerah tujuan.

8. Arus migrasi (migration stream), jumlah atau banyaknya perpindahan yang terjadi dari daerah asal ke daerah tujuan dalam jangka waktu tertentu.
Pada dasarnya orang berpindah tempat akan senantiasa didukung oleh berbagai alasan, alasan yang bersifat pribadi, alasan lingkungan dan lain sebagainya. Menurut Everett S. Lee (Mantra, 1985:181) ada 4 (empat) faktor yang perlu diperhatikan dalam studi migrasi penduduk, yaitu:

1. Faktor-faktor yang terdapat di daerah asal.

2. Faktor-faktor yang terdapat di tempat tujuan.

3. Rintangan antara.

4. Faktor-faktor individu.

Ada 2 (dua) faktor yang selalu terdapat di daerah asal maupun tujuan yang terkait dengan perpindahan penduduk yaitu faktor positif dan faktor negatif. Faktor positif yaitu faktor yang menarik seseorang untuk tidak meninggalkan daerah tersebut, dan faktor negatif yaitu faktor yang menyebabkan seseorang meninggalkan daerah tersebut.

\section{Gambar 1}

Faktor-Faktor yang Terdapat Pada Daerah Asal, Daerah Tujuan dan Rintangan Antara

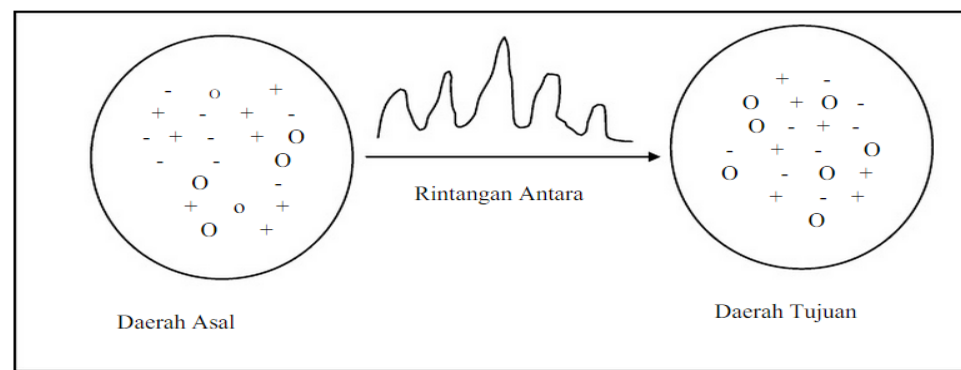

Sumber : Mantra, hal.181

Perubahan merupakan hal alamiah yang konstran terjadi dalam masyarakat, baik masyarakat tradisional maupun modern. Perubahan (perubahan sosial dan perubahan budaya) berlangsung secara terus menerus dan tidak dapat dihentikan, hanya dibedakan oleh tingkat kecepatan dan arah perubahan. Pada masyarakat tradisional perubahan terjadi secara lambat sedangkan pada masyarakat modern perubahan terjadi secara cepat. 
Terdapat perbedaan pendapat mengenai perubahan sosial dan perubahan budaya.

\section{Perubahan Sosial}

Perubahan sosial merupakan perubahan dalam segi struktur sosial dan hubungan sosial. Menurut Gillin John dan John Philip Gillin (Soerjono Soekanto, 1990: 335) perubahan sosial merupakan "Suatu variasi dari cara-cara hidup yang telah diterima, baik karena perubahan-perubahan kondisi geografis, kebudayaan material, komposisi penduduk, ideologi maupun karena adanya difusi ataupun penemuan-penemuan baru dalam masyarakat."

Definisi perubahan sosial dalam arti lain menurut Selo Soemardjan (1990: 327) adalah "Segala perubahan-perubahan pada lembaga-lembaga kemasyarakatan di dalam suatu masyarakat, yang mempengaruhi sistem sosialnya, termasuk di dalamnya nilai-nilai, sikap dan pola perilaku di antara kelompokkelompok dalam masyarakat."

Tekanan pada definisi tersebut terletak pada lembaga-lembaga kemasyarakatan sebagai himpunan pokok manusia, perubahanperubahan mana kemudian mempengaruhi segi-segi struktur masyarakat lainnya.

Lebih lanjut lagi menurut Astrid Susanto (Garna, 1992: 8) perubahan sosial merupakan "Adanya tekanan akan pentingnya pembangunan untuk diterapkan pada gejala sosial. Ada dua proses sosial yang dapat dikaitkan dengan pembangunan, yaitu pertumbuhan atau perkembangan pengetahuan dan pertumbuhan atau perkembangan kemampuan manusia untuk mengendalikan lingkungan alam. Sedangkan perkembangan (progress) tidak tergantung pada penafsiran arti dari sejarah, tetapi lebih didasarkan pada pengetahuan tentang kondisi dan cara-cara terjadinya perubahan sosial serta hal-hal yang menyangkut masyarakat tertentu."

Melihat uraian mengenai perubahan sosial yang telah dipaparkan sebelumnya, perubahan sosial antara lain bisa meliputi, perubahan dalam segi distribusi kelompok usia, tingkat pendidikan rata-rata, tingkat kelahiran penduduk, penurunan kadar rasa kekeluargaan dan informalitas antar tetangga karena adanya perpindahan orang dari desa ke kota, dan persebaran penduduk.

\section{Perubahan Budaya}

Perubahan budaya mencakup perubahan dalam segi budaya masyarakat. Perubahan budaya antara lain meliputi, penambahan kata-kata baru dalam penggunaan bahasa, perubahan konsep tata susila dan moralitas, bentuk seni baru, aturan-aturan atau norma-norma yang menjadi pegangan dalam kehidupan masyarakat, nilai-nilai, teknologi dan hasil karya manusia.

\section{Perubahan Sosial dan Budaya}

Perubahan yang terjadi di masyarakat hampir semuanya mencakup aspek perubahan sosial dan budaya. Oleh karena itu, penggunaan kedua istilah tersebut dalam hal perbedaannya tidak terlalu diperhatikan. Perubahan pada struktur masyarakat selalu berjalan seiring dengan perubahan kebudayaan dan fungsi suatu sistem sosial.

Unsur-Unsur dalam perubahan sosial budaya meliputi :

\section{Nilai dan norma sosial}

Hubungan antar manusia di dalam suatu masyarakat terlaksana sebagaimana yang diharapkan maka dirumuskan norma-norma masyarakat. Norma-norma yang ada dalam masyarakat mempunyai kekuatan mengikat yang berbeda-beda. Dalam Soerjono Soekanto (2007: 174) norma-norma dapat dibedakan berdasarkan kekuatan yang mengikatnya, secara sosiologis dikenal dengan adanya empat pengertian, yaitu :

a) Cara (usage), menunjuk pada suatu bentuk perbuatan. Cara (usage) lebih menonjol di dalam hubungan antarindividu dalam masyarakat. Sutu penyimpangan terhadapnya tidak akan mengakibatkan hukuman yang berat, 
akan tetapi hanya sekedar celaan dari individu yang dihubunginya.

b) Kebiasaan (folkways) menunjuk pada perbuatan yang diulang-ulang dalam bentuk yang sama membuktikan bahwa orang banyak menyukai perbuatan tersebut. Memiliki kekuatan mengikat yang lebih besar daripada cara.

c) Tata kelakuan (mores) mencerminkan sifat-sifat yang hidup dari kelompok manusia yang dilaksanakan sebagai alat pengawas, secara sadar maupun tidak sadar, oleh masyarakat terhadap anggota-anggotanya.

d) Adat-istiadat (custom) menunjuk pada tata kelakuan yang kekal serta kuat integrasinya dengan pola-pola perilaku masyarakat. Anggota masyarakat yang melanggar adat-istiadat akan menderita sanksi yang keras yang kadang-kadang secara tidak langsung diperlakukan.

2. Pola perilaku dan interaksi sosial

Menurut seorang sarjana psikologo, Woodworth dalam W.A Gerungan (2004: 59) pada dasarnya terdapat empat jenis hubungan antara individu dengan lingkungannya. Individu dapat bertentangan dengan lingkungan, individu dapat menggunakan lingkungannya, individu dapat berpartisipasi (ikut serta) dengan lingkungannya, dan individu dapat menyesuaikan dirinya dengan lingkungannya. Lingkungan dalam hal ini melalui baik lingkungan fisik yaitu alam benda-benda yang kongkret, maupun lingkungan psikis yaitu jiwa-raga orang-orang dalam lingkungan, atau lingkungan rohaniah, yaitu objective Geist, berarti keyakinankeyakinan, ide-ide, filsafat-filsafat yang terdapat di lingkungan individu itu, baik yang dikandung oleh orang-orangnya sendiri di lingkungannya maupun yang tercantum dalam buku-buku atau hasil kebudayaan lainnya. Menyesuaikan diri dapat diartikan dalam arti yang luas dan dapat berarti mengubah diri sesuai dengan keadaan lingkungan, tetapi juga mengubah lingkungan sesuai dengan keadaan (keinginan) diri.
3. Sistem peralatan hidup dan teknologi

Manusia selalu berusaha untuk mempertahankan hidupnya sehingga mereka akan selalu membuat peralatan atau bendabenda yang menunjang kebutuhan hidupnya. Sistem teknologi pada era modernisasi semakin menunjukkan kemajuan dalam hal kemudahan akses informasi oleh setiap elemen masyarakat. Adanya kemajuan teknologi telah banyak mengurangi tingkat kesulitan hidup masyarakat. Semakin canggih teknologi menyebabkan addanya kemudahan namun dalam perkembangannya yang terlihat mencolok adalah kemudahan dalam akses informasi dalam hal pengetahuan, komunikasi dan kemudahan akses masyarakat dalam beraktivitas.

Sistem peralatan hidup dan teknologi terbagi menjadi :

a) Alat-alat produktif, alat yang digunakan untuk memudahkan kegiatan manusia dalam proses produksi.

b) Makanan, aktifitas pengolahan berbagai macam bahan makanan dengan menggunakan teknologi.

c) Pakaian, aktifitas pengolahan jenis bahan pakaian menjadi pakaian layak pakai yang disesuaikan untuk kebutuhan pemakaian sehari-hari.

d) Tempat berlindung dan perumahan, tempat berlindung yang digunakan manusia dibuat dengan teknologi canggih untuk menambah kenyamanannya.

e) Alat transportasi, memegang peranan penting dalam kehidupan manusia. Digunakan sebagai penghubung antara satu tempat dengan tempat lainnya.

4. Sistem ekonomi dan mata pencaharian

Mata pencaharian atau aktivitas ekonomi suatu masyarakat menjadi fokus kajian penting. Sistem mata pencaharian mengkali bagaimana cara mata pencaharian suatu kelompok masyarakat atau sistem perekonomian mereka untuk mencukupi kebutuhan hidupnya. 
Sistem mata pencaharian atau ekonomi suatu yang berbasis pada sektor pertanian masih banyak ditemukan di daerha perdesaan yang relatif belum terpengaruh oleh arus modernisasi.

\section{Masalah Sosial}

Perubahan sosial budaya dapat menimbulkan masalah sosial. Masalah sosial erat kaitannya dengan kondisi sosial, karena masalah sosial ditimbulkan dari kondisi sosial budaya yang terjadi di masyarakat hasil dari interaksi ataupun interelasi dari dua manusia atau lebih.

Adapun karakteristik masalah sosial yang dipaparkan Edi Suharto (2005: 83) yaitu :

a) Kondisi yang dirasakan banyak orang. Suatu masalah baru dapat dikatakan sebagai masalah sosial apabila kondisinya dirasakan oleh banyak orang. Namun demikian, tidak ada batasan mengenai berapa jumlah orang yang harus merasakan masalah tersebut.

b) Kondisi yang dinilai tidak menyenangkan. Menurut faham hedonisme, orang cenderung mengulang sesuatu yang menyenangkan dan menghindari sesuatu yang tidak mengenakan. Orang senantiasa menghindari masalah karena masalah selalu tidak menyenangkan. Penilaian masyarakat sangat penting dalam menentukan suatu kondisi sebagai masalah sosial.

c) Kondisi yang menuntut pemecahan. Suatu kondisi yang tidak menyenangkan senantiasa menuntut pemecahan. Umumnya, suatu kondisi dianggap perlu dipecahkan jika masyarakat merasa bahwa kondisi tersebut memang dapat dipecahkan.

d) Pemecahan tersebut harus dilakukan melalui aksi sosial secara kolektif. Masalah sosial hanya dapat diatasi melalui rekayasa sosial seperti aksi sosial, kebijakan sosial atau perencanaan sosial karena penyebab dan akibatnya bersifat multidimensional dan menyangkut banyak orang.

\section{PENUTUP}

Masyarakat senantiasa mengalami masalah sosial dan memiliki kebutuhan. Penanganan masalah sosial harus mampu merespon segala macam perubahan dalam masyarakat yang senantiasa berubah.

\section{Daftar Pustaka}

Mantra, Ida Bagoes. 1985. Pengantar Studi Demografi. Yogyakarta: Nur Cahya.

Badan Pusat Statistik Kecamatan Kertajati. 2014. Kecamatan Kertajati Dalam Angka Tahun 2014. Majalengka : Badan Pusat Statistik Kabupaten Majalengka.

Gerungan, W.A. 2004. Psikologi Sosial. Ed. Ketiga. Bandung: Refika Aditama.

Ranjabar, Jacobus. 2015. Perubahan Sosial : Teori - Teori dan Proses Perubahan Sosial serta Teori Pembangunan. Bandung: Alfabeta.

Simandjutak, B. 1981. Perubahan dan Perencanaan Sosial. Bandung: Tarsito.

Soekanto, Soerjono. 1982. Sosiologi Suatu Pengantar. Ed. Baru 2007. Jakarta : PT Raja Grafindo Persada.

Suharto, Edi. 2005. Membangun Masyarakat Memberdayakan Rakyat : Kajian Strategis Pembangunan Kesejahteraan Sosial dan Pekerjaan Sosial. Bandung: Refika Aditama. 